\title{
Analysis of the hard and soft shading impact on photovoltaic module performance using solar module tester
}

\author{
Mustafa Hamid Al-Jumaili ${ }^{1}$, Ahmed Subhi Abdalkafor ${ }^{2}$, Mohammed Qasim Taha ${ }^{3}$ \\ ${ }^{1}$ Renewable Energy Research Center (RERC), University of Anbar, Iraq \\ ${ }^{2}$ Career Development Center, University of Anbar, Iraq \\ ${ }^{3}$ College of Applied Sciences-Hit, University of Anbar, Iraq
}

\begin{tabular}{l} 
Article Info \\
\hline Article history: \\
Received Oct 12, 2018 \\
Revised Jan 20, 2019 \\
Accepted Mar 4, 2019 \\
\hline Keywords: \\
Maximum power point, \\
Photovoltaic, \\
Shading, \\
Solar module tester, \\
Solara ${ }^{\circledR}$ PV.
\end{tabular}

\begin{abstract}
Solar cells are a major alternate source of sustainable energy in the usual condition of depleting non- renewable energy sources. Nowadays, this source is getting more and more important due to its use in large and small-scale installations. One of the major causes of energy losses in photovoltaic (PV) modules is the shading. It can happen due to clouds passing, near trees, and/or neighboring structures. Generally, there are two types of PV module Shading which are either partial shading or complete shading. Both have a significant impact on the solar module output power. This paper is an attempt of carrying out a study of the electrical characteristics of a solar module with various percentages of simulated shading. The solar module tester (SMT) simulator was used in this study. The study approved the direct correlation between short-circuit current and solar irradiance. The advantage of using SMT is its stable irradiance in comparison to the practical unstable solar irradiance within the same period. The results of both methods of shading simulation show that shading has a significant impact on the performance of solar panel in terms of efficiency, fill factor and output power. For better performance, solar panels should install in shading free places as much as it is possible.
\end{abstract}

Copyright (C) 2019 Institute of Advanced Engineering and Science. All rights reserved.

\section{Corresponding Author:}

Mohammed Qasim Taha, College of Applied Sciences-Hit, University of Anbar, Iraq.

Email: as.mohammad_taha@uoanbar.edu.iq

\section{INTRODUCTION}

Lately, sustainable energy has become a hot topic attracting a lot of researcher's interest. Energy is a highly needed source for nation's development, yet traditional energy sources are considered as highly depleted sources. All that leads to researching new energy resources such as wind, water, the geothermal and solar energy. Solar energy is inexhaustible green energy, and environmentally friendly [1]. Fossil fuel will continue dominating the main global energy consumption. Nations' awareness of fossil fuel using and the planet's carbon emissions because of climate change and global warming [2]. Therefore, sustainable energy resources such as wind and solar energy will play an important role in the energy of the world in the near future [3]. Solar energy is a promising option for renewable energy and it has gained the interest of the world. Conversion of solar energy into electrical energy is static, quiet, and environment-friendly [4]. Therefore, photovoltaic industry growth was very fast in past years. Photovoltaic (PV) system performance is affected by several factors including the strength of irradiance, shading, temperature, degradation, soiling, mismatch losses, tilt angle etc.

Non-ideal operating conditions is one of the most affecting parameters on the PV system performance. One of these non-ideal conditions is working under reduced irradiance due shading effect [5]. Shading may be uniform or nonuniform if it covers the whole surface of the panel is considered as uniform 
shading. While if the shading covers only part of the PV panel then it considered as a non-uniform shading. In both cases, it has a significant impact on the solar cell output power [6]. Under partial shading conditions, the power from the PV module can be dramatically reduced and maximum power point tracking control will be affected [1]. The accurate partial shading modeling of PV system was introduced in ref. [7, 8]. The authors were used a two-diode model to represent the PV cell. The model requires only four parameters to get better accuracy at low irradiance level, allowing for more accurate prediction of PV system performance during partial shading condition. A large array simulation model was used and interfaced with MPPT algorithms and power electronic converters [9]. The accurateness of the modeling technique was validated by real-time simulator data and compared with the Neural Network model, P\&O and single-diode model. This study is very useful for companies and expertise in the field of renewable energy because of its accuracy, simplicity, and the fast of applying [10].

The available photovoltaic modules have the configuration of series-connected, parallel connected or combination of both connections of cells. Some parameters have a direct effect on the output of any solar module such as solar irradiance, cell temperature, tilt angle shaded condition. Therefore, the generated electricity of a solar panel is highly affected by the strength of solar irradiance. The amount of falling sunlight on the module determines the current generated by a PV module [11, 12]. Based on this background and since the solar irradiance level is not at standard level $(1000 \mathrm{~W} / \mathrm{m} 2)$ most of the daytime, this paper aims to analyze and study the effect of shading on whole and a partial surface of the PV module based on solar module tester. Pulsed light and decaying solar simulator are used in our simulation which has the ability of control the solar irradiance level, calculating the series resistance of module fill factor, short circuit voltage, open circuit voltage, short circuit current, peak power, and the temperature during the test.

\section{SOLAR SIMULATOR}

Currently, three types of solar simulators are available [13]: the first type is constant light simulator which needs heat load, cooling, and high power consumption. The second type is pulsed light simulator where there is no sample heating, fast measurement, and no temperature leveling. The third type is the pulsed light with the decaying simulator, this simulator can measure different levels of irradiation, series resistance measurement, and high peak irradiance can be reached easily [14]. The standard parameters of solar cell classes are given in Table 1.

Table 1. Standard parameters for solar simulators classes according to ASTM standard

\begin{tabular}{cccc}
\hline Classification & $\begin{array}{c}\text { Spectral Match } \\
\text { (each interval) }\end{array}$ & $\begin{array}{c}\text { Irradiance Spatial } \\
\text { Non-Uniformity }\end{array}$ & Temporal Instability \\
\hline Class A & $0.75-1.25$ & $2 \%$ & $2 \%$ \\
Class B & $0.6-1.4$ & $5 \%$ & $5 \%$ \\
Class C & $0.4-2.0$ & $10 \%$ & $10 \%$ \\
\hline
\end{tabular}

\section{SOLAR CELL MATHEMATICAL MODEL}

A single diode solar cell equivalent circuit is shown in Figure 1, the equivalent circuit consists of a parallel connected current source with a diode and the whole group is connected in series with the resistance. There is a direct proportion between the falling light on the cell and its output current (photocurrent IL). The solar cell is considered as inactive device during the night time or full darkness, instead, the cell works as a p$\mathrm{n}$ junction diode. It doesn't produce any power in terms of current or voltage. Yet, it will generate a current called dark current or diode current when it is connected to an external power supply with a large voltage. The diode type determines the I-V characteristics of the cell, a detailed algorithm of the single diode solar cell equivalent circuit is given by refs. $[15,16]$.

The reason for choosing Solara ${ }^{\circledR}$ PV for modeling in this paper is the suitability of this module to the traditional applications of a PV solar system. The used Solara ${ }^{\circledR}$ PV module has 36 polycrystalline silicon cells in a series connecting and it is providing a nominal maximum power of $130 \mathrm{~W}$. Standard conditions test are used for data measurements by a solar simulator, which is: Illumination of $1 \mathrm{~kW} / \mathrm{m} 2$ at AM 1.5 spectral distribution and temperature of the module of $25 \mathrm{C}$ or as specified on curves.

A Solar Module Tester (SMT) (module type: GSMT, class-AAA) can extract the most PV characteristics [17]. The SMT exists in the laboratory of Renewable Energy Research Center-University of Anbar as shown in Figure 2, and is used for evaluation of shading effect on the performance of Solara ${ }^{\circledR} 130 W$ panel. All analysis has been done by an scmt \#286 DAQ-2017 software. The PV panel is in a horizontal plane at standard height and more than one test on the panel can be done (i.e. without shading,

Analysis of the hard and soft shading impact on photovoltaic module ... (Mustafa Hamid Al-Jumaili) 
$25 \%$ shading, $50 \%$ shading, $75 \%$ shading, $100 \%$ shading). Finally, one full cell is shaded on the lowest right and left cells and one row also shaded at one of the middle rows of the panel.

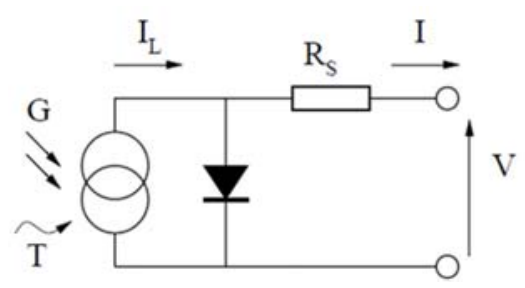

Figure 1. Solar cell with single-diode and series resistance

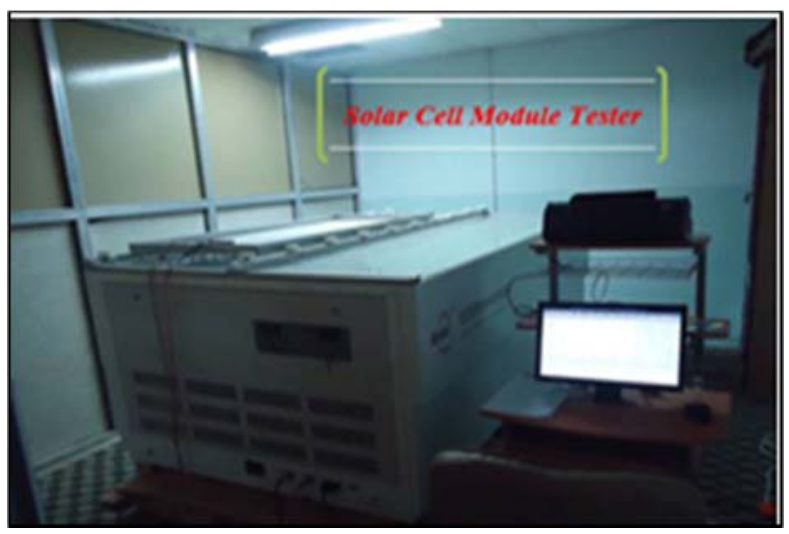

Figure 2. The solar module tester at the lab of renewable energy research center

Table 2 provides a detailed specification of Solara ${ }^{\circledR} 130 \mathrm{~W}$ PV module. A simulation of shading is done at the renewable energy research center lab and the module is shaded by using tapes of the carton.

Table 2. Specification of solara ${ }^{\circledR}$ PV panel

\begin{tabular}{cc}
\hline Parameter & Solara (Germany) \\
\hline Vmax (Volt) & 17.8 \\
Imax (Ampere) & 7.3 \\
Voc (Volt) & 21.7 \\
Isc (Ampere) & 8.18 \\
Pout (Watt) & 130 \\
\hline
\end{tabular}

\section{EXPERIMENTAL WORK}

In this section, it can be shown the effect of the shading by using a SMT on the electrical output power of the solar panel. The shading comes from various resources such as clouds, trees, high buildings in front of panels, and other blocks that prevent the sun's radiation to be distributed equally on the surface of panels. In our simulation, four cases of shading are considered; these are shading- $25 \%$, shading- $50 \%$, shading-75\%, and shading-100\%.

Figure 4 illustrates the I-V and P-V characteristic curves for a model of Solara ${ }^{\circledR} 130 \mathrm{~W}$ at nonshading. Note that the maximum power of this model is the same power of model in the nameplate from the supplied company. The other calculated parameters shown beside the figure is the same parameters as the manufacturing company given in Table 2 . While it is difficult to get the same power of panel due to the fluctuation in the solar radiation at the site of the university (due to dusty weather or other effects). Also, the practical simulation of shading effect needs time to simulate all four percentages of shadings at the same time. So, the SMT is more reliable for doing such tests. The fill factor of a PV panel in the table beside 
Figure 3 is the ratio of the PV cells actual power output (Vpm x Ipm) versus its dummy output power (Voc $\mathrm{x}$ Isc). The evaluating of solar cells performance is highly depending on fill factor ratio.

Typically, the fill factor of commercial solar cells is $>0.7$. The crystalline cells fill factor lies between 0.4 and 0.65 on grade B, while in thin film solar cells or amorphous cells between 0.4 and 0.7 . The solar cell series resistance can be determined using the ratio of fill factor. The fill factor is a parameter of interest given by the relation [12]:

$$
\mathrm{FF}=(\mathrm{Vpm} * \mathrm{Ipm}) /\left(\operatorname{Voc}^{*} \mathrm{Isc}\right)
$$

The photovoltaic conversion efficiency, another important parameter, measures the amount of light energy that can be converted into electrical energy and is given by [13]:

$$
\eta=\mathrm{Pm} / \mathrm{Pin}=\mathrm{FF}^{*} \mathrm{Isc}^{*} \mathrm{Voc} / \mathrm{Pin}
$$

Where $\mathrm{Pm}$ is the maximum power of the device and Pin is the incident power.

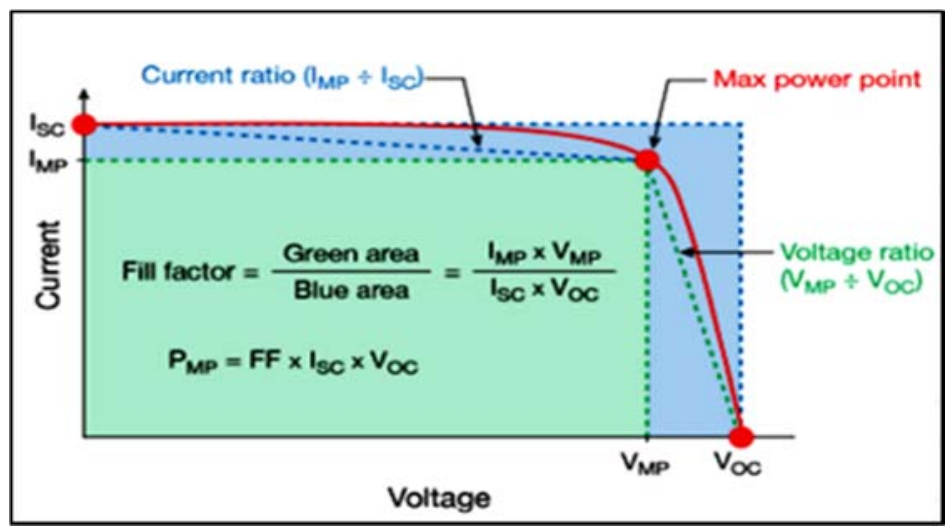

Figure 3. The fill factor of a solar panel

The lower fill factor produces less power at its maximum power point contrasted with the higher fill factor of the panel. To specify the solar cell grade, every single solar panel is tested for its fill factor during the manufacturing process of commercial grade solar panels. If the fill factor below 0.7 , the panels are considered as Grade-B cells, then they are sliced and may be used for a personal or any other use. In Figure 4 the fill factor is $72.36 \%$ which is within the accepted range.

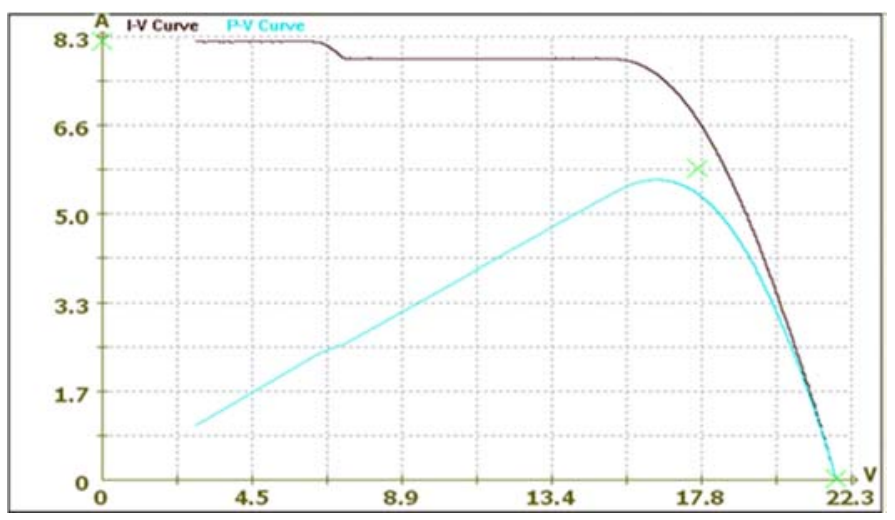

\begin{tabular}{cc}
\hline Factors & Amplitude \\
\hline $\mathrm{I}_{\mathrm{sc}}$ & $8.160 \mathrm{~A}$ \\
$\mathrm{I}_{\mathrm{pm}}$ & $7.273 \mathrm{~A}$ \\
$\mathrm{~V}_{\mathrm{oc}}$ & $21.872 \mathrm{~V}$ \\
$\mathrm{~V}_{\mathrm{pm}}$ & $17.756 \mathrm{~V}$ \\
$\mathrm{P}_{\mathrm{m}}$ & $129.140 \mathrm{~W}$ \\
$\mathrm{FF}$ & $72.36 \%$
\end{tabular}

Figure 4. Simulation results at no shading for Solara ${ }^{\circledR}$ 130W PV panel 
Figure 5 shows the I-V and P-V characteristic curves at $25 \%$ soft shading. From this figure, its clear that the maximum power $(\mathrm{Pm})$, the voltage at peak power (Vpm) and fill factor (FF) are decreased as the module subjected to shading effect. The output power is reduced by about $41 \%$ in reference to the nonshading case. Under hard shading effect with the same shading percentage ( $25 \%$ shading) the output power is reduced by about $57 \%$ as shown in Figure 6 . The open circuit voltage (Voc) still approximately at the same values while the short circuit current (Isc) and peak power current (Ipm) are widely reduced.

Figures 7 to 11 represent the performance of module when the shading increased to high values, i.e. $50 \%, 75 \%$, and $100 \%$. It is clear from the extracted result the effect of shading on the performance of modules. Also, the hard shading has more effect on the panel's performance. As the shading increases, the power of the module decreases. In Figure 11, the output of module approached to zero which is the normal case due to non-existing of solar radiation due to full shading effect.

Figures 7 to 11 represent the performance of module when the shading increased to high values, i.e. $50 \%, 75 \%$, and $100 \%$. It is clear from the extracted result the effect of shading on the performance of modules. Also, the hard shading has more effect on the panel's performance. As the shading increases, the power of the module decreases. In Figure 11, the output of module approached to zero which is the normal case due to non-existing of solar radiation due to full shading effect.

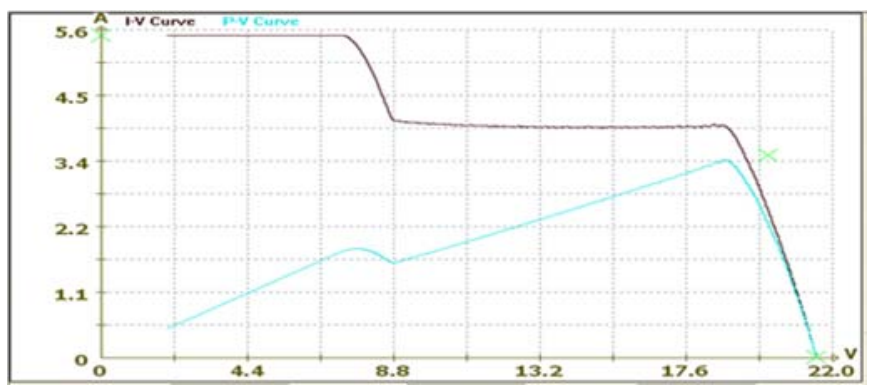

\begin{tabular}{cc}
\hline Factors & Amplitude \\
\hline $\mathrm{I}_{\mathrm{sc}}$ & $5.491 \mathrm{~A}$ \\
$\mathrm{I}_{\mathrm{pm}}$ & $3.799 \mathrm{~A}$ \\
$\mathrm{~V}_{\mathrm{oc}}$ & $21.544 \mathrm{~V}$ \\
$\mathrm{~V}_{\mathrm{pm}}$ & $20.078 \mathrm{~V}$ \\
$\mathrm{P}_{\mathrm{m}}$ & $75.858 \mathrm{~W}$ \\
$\mathrm{FF}$ & $64.12 \%$ \\
\hline
\end{tabular}

Figure 5. Soft shading on $25 \%$ of the panel area

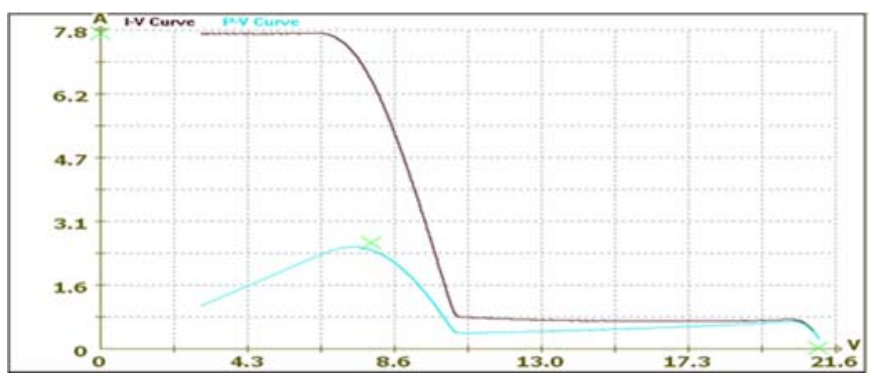

\begin{tabular}{cc}
\hline Factors & Amplitude \\
\hline $\mathrm{I}_{\mathrm{sc}}$ & $7.760 \mathrm{~A}$ \\
$\mathrm{I}_{\mathrm{pm}}$ & $6.972 \mathrm{~A}$ \\
$\mathrm{~V}_{\mathrm{oc}}$ & $21.125 \mathrm{~V}$ \\
$\mathrm{~V}_{\mathrm{pm}}$ & $7.982 \mathrm{~V}$ \\
$\mathrm{P}_{\mathrm{m}}$ & $55.619 \mathrm{~W}$ \\
$\mathrm{FF}$ & $34.17 \%$ \\
\hline
\end{tabular}

Figure 6. Hard shading on $25 \%$ of the panel area

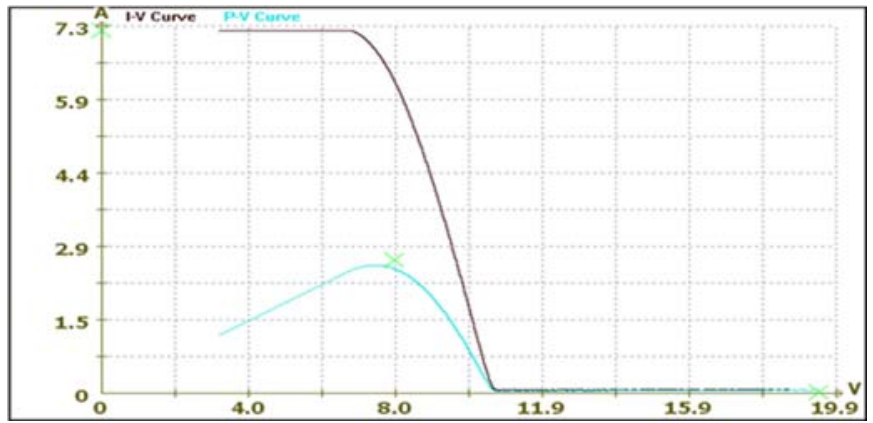

\begin{tabular}{cc}
\hline Factors & Amplitude \\
\hline $\mathrm{I}_{\mathrm{sc}}$ & $7.250 \mathrm{~A}$ \\
$\mathrm{I}_{\mathrm{pm}}$ & $6.628 \mathrm{~A}$ \\
$\mathrm{~V}_{\mathrm{oc}}$ & $19.453 \mathrm{~V}$ \\
$\mathrm{~V}_{\mathrm{pm}}$ & $7.953 \mathrm{~V}$ \\
$\mathrm{P}_{\mathrm{m}}$ & $52.700 \mathrm{~W}$ \\
$\mathrm{FF}$ & $37.37 \%$ \\
\hline
\end{tabular}

Figure 8 . Hard shading on $50 \%$ of the panel area

Int J Pow Elec \& Dri Syst, Vol. 10, No. 2, June 2019: 1014 - 1021 
Figure 12 illustrates the effect of shading on one cell inside the panel which lies at the lowest left. Even one cell is shaded; the output power is reduced by about $57 \%$ of the total power (i.e. 1$55.814 / 129.140=56.78 \%$ ). As the location of a shaded cell varies, then the reduction of power will remain has the same previous effect in Figure 12, and the effect is shown in Figure 13 which represents the shading on one cell lies at the middle of the panel. Figure 14 shows the effect of shading in case of one row is fully shaded. From this figure, the output power is also approached to zero. Finally, Figure 15 summarizes the results of the shading effect at different percentages with soft and hard shading.

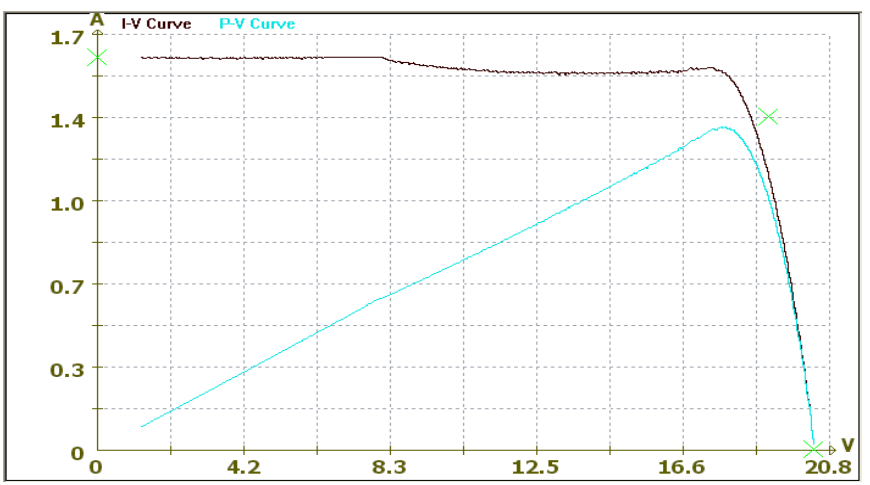

\begin{tabular}{cc}
\hline Factors & Amplitude \\
\hline $\mathrm{I}_{\mathrm{sc}}$ & $1.595 \mathrm{~A}$ \\
$\mathrm{I}_{\mathrm{pm}}$ & $1.478 \mathrm{~A}$ \\
$\mathrm{~V}_{\mathrm{oc}}$ & $20.366 \mathrm{~V}$ \\
$\mathrm{~V}_{\mathrm{pm}}$ & $19.072 \mathrm{~V}$ \\
$\mathrm{P}_{\mathrm{m}}$ & $28.181 \mathrm{~W}$ \\
$\mathrm{FF}$ & $86.78 \%$
\end{tabular}

Figure 9 . Soft shading on $75 \%$ of the panel area

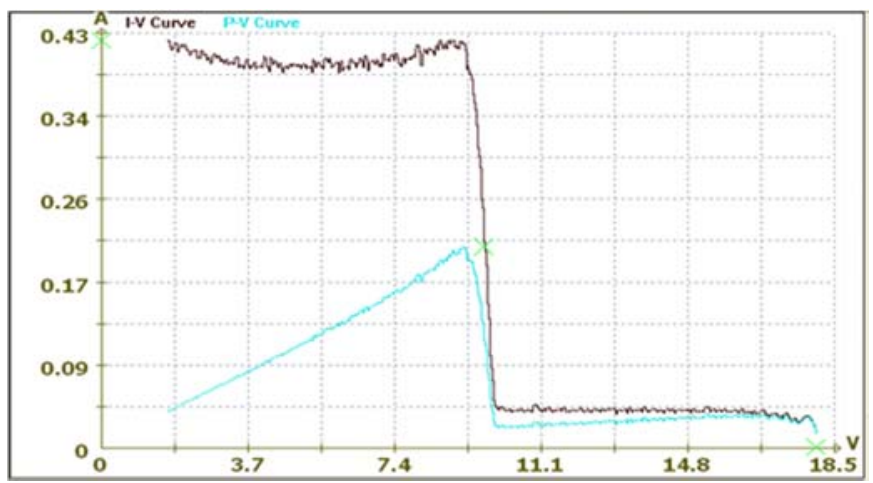

\begin{tabular}{cc}
\hline Factors & Amplitude \\
\hline $\mathrm{I}_{\mathrm{sc}}$ & $0.421 \mathrm{~A}$ \\
$\mathrm{I}_{\mathrm{pm}}$ & $0.399 \mathrm{~A}$ \\
$\mathrm{~V}_{\mathrm{oc}}$ & $18.048 \mathrm{~V}$ \\
$\mathrm{~V}_{\mathrm{pm}}$ & $9.675 \mathrm{~V}$ \\
$\mathrm{P}_{\mathrm{m}}$ & $3.875 \mathrm{~W}$ \\
$\mathrm{FF}$ & $50.71 \%$ \\
\hline
\end{tabular}

Figure 10 . Hard shading on $75 \%$ of the panel area

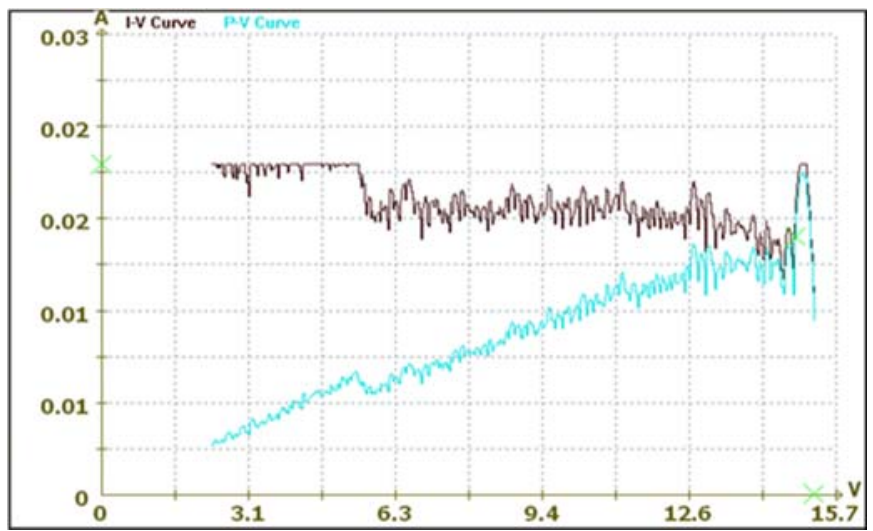

\begin{tabular}{cc}
\hline Factors & Amplitude \\
\hline $\mathrm{I}_{\mathrm{sc}}$ & $0.021 \mathrm{~A}$ \\
$\mathrm{I}_{\mathrm{pm}}$ & $0.018 \mathrm{~A}$ \\
$\mathrm{~V}_{\mathrm{oc}}$ & $15.247 \mathrm{~V}$ \\
$\mathrm{~V}_{\mathrm{pm}}$ & $14.852 \mathrm{~V}$ \\
$\mathrm{P}_{\mathrm{m}}$ & $0.263 \mathrm{~W}$ \\
$\mathrm{FF}$ & $80.35 \%$ \\
\hline
\end{tabular}

Figure 11. Shading on $100 \%$ of the panel area 


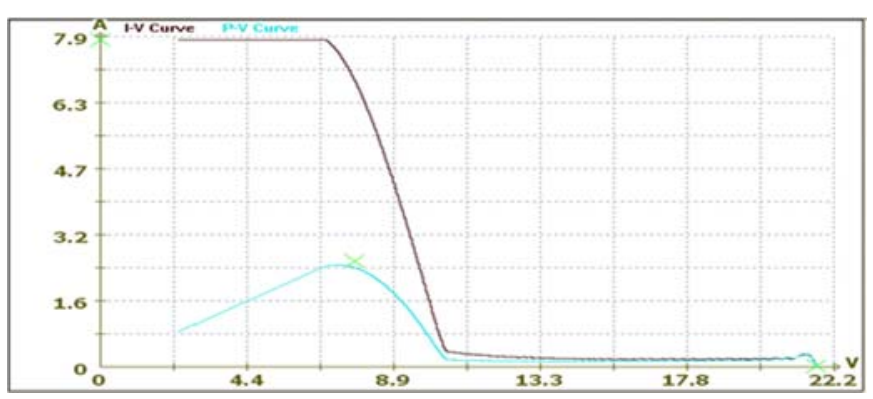

\begin{tabular}{cc}
\hline Factors & Amplitude \\
\hline $\mathrm{I}_{\mathrm{sc}}$ & $7.793 \mathrm{~A}$ \\
$\mathrm{I}_{\mathrm{pm}}$ & $7.228 \mathrm{~A}$ \\
$\mathrm{~V}_{\mathrm{oc}}$ & $21.705 \mathrm{~V}$ \\
$\mathrm{~V}_{\mathrm{pm}}$ & $7.725 \mathrm{~V}$ \\
$\mathrm{P}_{\mathrm{m}}$ & $55.814 \mathrm{~W}$ \\
$\mathrm{FF}$ & $33.00 \%$ \\
\hline
\end{tabular}

Figure 12. Shading on the lowest left cell of the panel

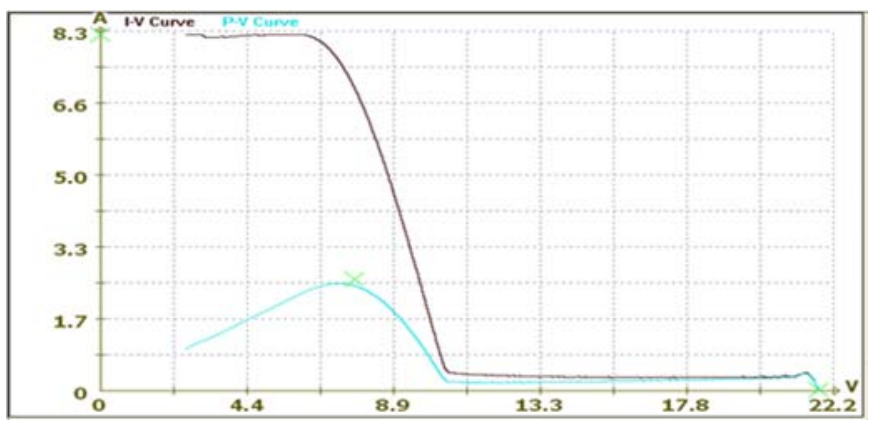

\begin{tabular}{cc}
\hline Factors & Amplitude \\
\hline $\mathrm{I}_{\mathrm{sc}}$ & $8.212 \mathrm{~A}$ \\
$\mathrm{I}_{\mathrm{pm}}$ & $7.365 \mathrm{~A}$ \\
$\mathrm{~V}_{\mathrm{oc}}$ & $21.769 \mathrm{~V}$ \\
$\mathrm{~V}_{\mathrm{pm}}$ & $7.721 \mathrm{~V}$ \\
$\mathrm{P}_{\mathrm{m}}$ & $56.836 \mathrm{~W}$ \\
$\mathrm{FF}$ & $31.79 \%$ \\
\hline
\end{tabular}

Figure 13. Shading of one cell located at the middle of panel.

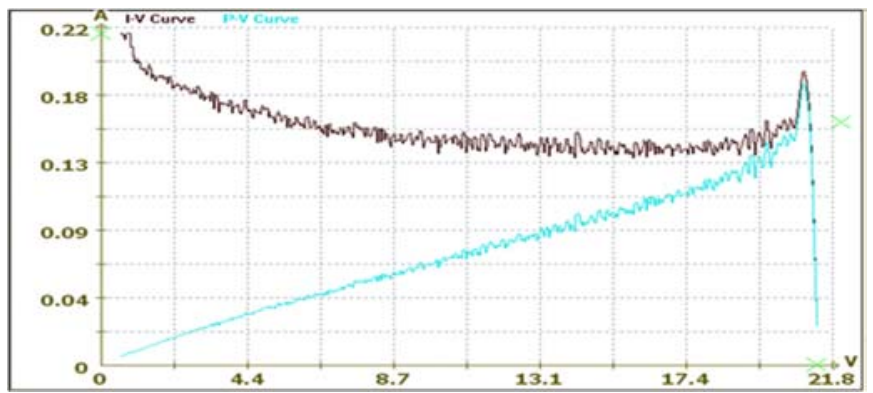

\begin{tabular}{cc}
\hline Factors & Amplitude \\
\hline $\mathrm{I}_{\mathrm{sc}}$ & $0.216 \mathrm{~A}$ \\
$\mathrm{I}_{\mathrm{pm}}$ & $0.156 \mathrm{~A}$ \\
$\mathrm{~V}_{\mathrm{oc}}$ & $21.349 \mathrm{~V}$ \\
$\mathrm{~V}_{\mathrm{pm}}$ & $22.086 \mathrm{~V}$ \\
$\mathrm{P}_{\mathrm{m}}$ & $3.451 \mathrm{~W}$ \\
$\mathrm{FF}$ & $74.89 \%$ \\
\hline
\end{tabular}

Figure 14. Shade of the entire middle row of the panel

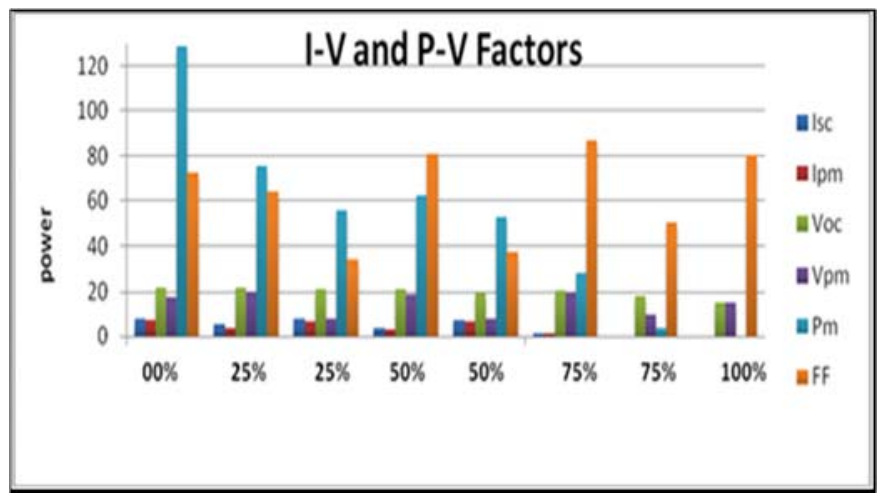

Figure 15. Summary of results for both hard and soft shading at different shading percentages from $0 \%$ to $100 \%$. 


\section{CONCLUSION}

In this study, the effect of the hard and soft shading on PV module performance was investigated by using the solar module tester. The results show that the shading can play an important role in the performance of PV systems. The solar module tester was used to simulate the standard sun radiation $(1000 \mathrm{~W} / \mathrm{m} 2)$. The output power of module was reduced by $41 \%$ when the shading was $25 \%$ of the panel area and the power of module was zero at complete hard shading case. When one cell was shaded, the power reduced by $57 \%$. So, it is important to choose the suitable site for installing the solar system to get the maximum power from the modules.

\section{ACKNOWLEDGMENT}

This research is supported and revised by the Scientific Committee in the Renewable Energy Research Center at the University of Anbar.

\section{REFERENCES}

[1] Y. Jiang, J. A. A. Qahouq and M. Orabi, "Matlabsolara PV/Pspice Hybrid Simulation Modeling of Solar PV Cell/Module," in Twenty-Sixth Annual ConferenceApplied Power Electronics Conference and Exposition (APEC), 6-11 march-2011, 2011.

[2] S. Samal and P. K. Hota, "Power Quality Improvement by Solar Photo-voltaic / Wind Energy Integrated System Using Unified Power Quality Conditioner," International Journal of Power Electronics and Drive System (IJPEDS), Vol. 8, No. 3, September 2017, pp. 1416-1426.

[3] H. Tsai, "Insolation-oriented model of photovoltaic module using Matlab/Simulink," Solar Energy, vol. 84, no. 7, pp. 1318-1326, 2010

[4] Syafaruddin, E. Karatepe and T. Hiyama, "Polar coordinate fuzzy controller based real-time maximum-power point control of photovoltaic system," Renewable Energy, vol. 34, no. 12, pp. 2597-2606, 2009.

[5] E. V. Paraskevadaki and S. A. Papathanassiou, "Evaluation of MPP Voltage and Power of mc-Si PV Modules in Partial Shading Conditions," IEEE Transaction on Energy Conversion, vol. 26, no. 3, 2011.

[6] KashifIshaque, Z. Salam and Syafaruddin, "A comprehensive Matlab Simulink PV system simulator with partial shading capability based on two-diode model," Solar Energy, vol. 85, p. 2217-2227, 2011.

[7] KashifIshaque, Z. Salam, H. Taheri and Syafaruddin, "Modeling and simulation of photovoltaic (PV) system during partial shading based on a two-diode model," Simulation Modelling Practice and Theory, vol. 19, p. 1613-626, 2011.

[8] H. Patel and V. Agarwal, "Matlab-based modeling to study the effects of partial shading on PV array characteristics," IEEE Transaction on Energy Conversion, vol. 23, no. 1, pp. 302-310, 2008.

[9] Mohammed Qasim Taha, Mustafa H. Al-Jumaili, Abdullah Khalid Ahmed, "Modeling the dielectric mediums impact on coaxial transmission line performance", Journal of Engineering and Applied Sciences, Volume 13 Issue 20, 2018.

[10] Younes S. Alwan, Mohammad Sami Zidan, Mohammed Qasim Taha, "Evaluation of Mobile Microwave Electric Field Severity at Al-Door Residential Complex in Iraq", Indonesian Journal of Electrical Engineering and Computer Science (IJEECS), Vol 14, No 3: June 2019.

[11] G. Walker, "Evaluating MPPT Converter Topologies Using Matlab PV Model," University of Queensland, 2016.

[12] E. H. Sabbar, M. H. Saleh, S. M. Salih and S. H. Salih, "Deposition of SeTe/Si Thin Film via Thermal Evaporation," American Journal of Condensed Matter Physics, vol. 3, no. 5, pp. 119-122, 2013.

[13] Ehsan H. Sabbar, Mustafa. H. Saleh and Salih M. Salih, "A Fabricated Solar Cell from ZnO/a-Si/Polymers," International Journal of Advanced Science and Technology, vol. 44, pp. 89-98, July, 2012.

[14] Mohammed Qasim Taha, Aymen Lpiza, "Design a New PWM Switching Technique in Multilevel Converters", IEEE Connecticut Conference on Industrial Electronics Technology \& Automation 2016, University of Bridgeport, CT, United States of America, October 14, 2016 - October 15, 2016.

[15] M. Villalva, J. Gazoli and E. Filho, "Modeling and circuit based simulation of photovoltaic arrays," in Proceedings of Power Electronics Conference, Bonito, Brazil, 2009.

[16] Abdelkader Mezouari, R. Elgouri, M. Alareqi, K. Mateur, H. Dahou4, L. Hlou, "A New Photovoltaic Blocks Mutualization System for Micro-Grids Using an Arduino Board and Labview" International Journal of Power Electronics and Drive System (IJPEDS), Vol. 9, No. 1, March 2018, pp. 98-104

[17] C. S. Chin, P. Neelakantan, S. S. Yang, B. Chua and K. T. K. Teo, "Effect of Partially Shaded Conditions on Photovoltaic Array’s Maximum Power Point Tracking," IJSSST, vol. 12, no. 3, pp. 52-59, 2012. 